Journal of Nutrition College, Volume 3, Nomor 1, Tahun 2014, Halaman 34 - 42

Online di : http://ejournal-s1.undip.ac.id/index.php/jnc

\title{
HUBUNGAN SKOR FREKUENSI DIET BEBAS GLUTEN BEBAS CASEIN DENGAN SKOR PERILAKU AUTIS
}

\author{
Rifmie Arfiriana Pratiwi, Fillah Fithra Dieny ${ }^{*}$ \\ Program Studi Ilmu Gizi Fakultas Kedokteran Universitas Diponegoro \\ Jl.Dr.Sutomo No.18, Semarang, Telp (024) 8453708, Email : gizifk@ undip.ac.id
}

\begin{abstract}
Background: One of the efforts to minimize the incidence of autism behavior is avoiding foods that contain gluten and casein because there is a hipermeability in the intestinal mucosa of an autism, resulting in two types of protein are difficult to digest and will form a substance called peptides.Gluten peptides produce gluteomorphin or gliadimorphin and casein peptide form caseomorphin. Both of these substances can affect the central nervous system, resulting a behavioral disorders.

Methods: Observational study with cross-sectional design in Ananda Educational Therapy Center Bekasi. Samples were 30 subjects and they were selected with purposive sampling. Data collected include the identity of the sample that determined with the age of autism diagnostic, weight and height, birth weight, parental characteristics data, age of mother during pregnancy, frequency of gluten-free casein-free diet scores were measured by $F F Q$ and behavioral observation were measured by questionnaire sheet behavior ICD-10. Bivariate analyzed with Pearson Product Moment Correlation test.

Results: Autism was higher in males (83.3\%) than women. The most dominant age diagnosed with autism between 1-2 years (53.3\%) and the most of them had normal nutritional status (46.7\%), but some of them (40\%) were overweight and obese. The autism behavior score is only (26.7\%) subject which is decreased. All (100\%) of subjects in this study still eating food which content of gluten and casein. Bivariate analysis showed that there was a significant correlation between frequency of gluten-free casein-free diet scores with the autism behavior scores $(r=0.369, p=0.045)$.
\end{abstract}

Conclusion: There was a significant correlation between frequency of gluten-free casein-free diet scores with the autism behavior scores.

Keywords: Diet score; casein; gluten; autism behavior

\begin{abstract}
ABSTRAK
Latar Belakang: Salah satu upaya untuk mengurangi terjadinya perilaku autis, yaitu dengan cara menghindari makanan yang mengandung gluten maupun casein sebab pada penderita autis terjadi hipermeabilitas mukosa usus yang mengakibatkan kedua jenis protein tersebut sulit dicerna dan akan membentuk suatu zat yang disebut peptide. Peptide gluten menghasilkan gluteomorphin atau gliadimorphin dan peptide casein membentuk caseomorphin. Kedua zat tersebut dapat mempengaruhi sistem saraf pusat sehingga menimbulkan gangguan perilaku.

Metode: Penelitian observasional dengan desain cross sectional yang dilakukan di Pusat Terapi Pendidikan Ananda Bekasi. Jumlah sampel sebanyak 30 subjek yang dipilih menggunakan metode purposive sampling. Data yang dikumpulkan, meliputi data identitas sampel berupa usia terdiagnosis autis, berat badan dan tinggi badan, berat badan saat lahir, data karakteristik orangtua, usia ibu saat hamil subjek, data skor frekuensi diet bebas gluten bebas casein diperoleh melalui FFQ serta data pengamatan perilaku yang diperoleh melalui kuesioner lembar perilaku ICD-10. Analisis bivariat dilakukan dengan uji korelasi Pearson Product Moment.

Hasil: Penderita autis lebih banyak ditemukan pada laki-laki (83,3\%) dibandingkan perempuan. Usia terdiagnosis autis paling dominan antara 1-2 tahun (53,3\%) dan sebagian besar status gizinya normal (46,7\%), tetapi adapula subjek (40\%) yang mengalami overweight dan obesitas. Subjek yang mengalami penurunan perilaku autis sebesar (26,7\%). Seluruh (100\%) subjek pada penelitian ini masih mengonsumsi makanan yang mengandung gluten maupun casein. Hasil uji bivariat menunjukkan ada hubungan antara skor frekuensi diet bebas gluten bebas casein dengan skor perilaku autis ( $r=0.369, p=0.045)$.
\end{abstract}

Simpulan: Terdapat hubungan antara skor frekuensi diet bebas gluten bebas casein dengan skor perilaku autis.

Kata kunci : skor diet; casein; gluten; perilaku autis

\section{PENDAHULUAN}

Autis merupakan suatu gangguan perkembangan yang sangat kompleks pada anak, mulai tampak sebelum usia 3 tahun. Kondisi ini menyebabkan mereka tidak mampu berkomunikasi maupun mengekspresikan keinginannya, sehingga mengakibatkan terganggunya perilaku dan hubungan dengan orang lain. Prevalensi autis beberapa tahun terakhir ini mengalami kenaikan yang signifikan. Center for Diseases Control and

${ }^{*}$ Penulis Penanggungjawab 
Prevention $(C D C)$ di Amerika Serikat pada bulan Maret 2013 melaporkan, bahwa prevalensi autis meningkat menjadi 1:50 dalam kurun waktu setahun terakhir. Hal tersebut bukan hanya terjadi di negara-negara maju seperti Inggris, Australia, Jerman dan Amerika namun juga terjadi di negara berkembang seperti Indonesia. Prevalensi autis di dunia saat ini mencapai $15-20$ kasus per 10.000 anak atau berkisar 0,15-0,20\%. Jika angka kelahiran di Indonesia 6 juta per tahun maka jumlah penyandang autis di Indonesia bertambah $0,15 \%$ atau 6.900 anak per tahunnya. ${ }^{1}$

Perilaku autis digolongkan menjadi dua jenis yaitu perilaku yang eksesif (berlebihan) dan perilaku defisit (berkekurangan). Perilaku eksesif adalah perilaku yang hiperaktif dan tantrum (mengamuk) seperti menjerit, mengepak, mengigit, mencakar, memukul, dan termasuk juga menyakiti diri sendiri (self abuse). Perilaku defisit adalah perilaku yang menimbulkan gangguan bicara atau kurangnya perilaku sosial seperti tertawa atau menangis tanpa sebab serta melamun. ${ }^{2}$ Perilaku autis dapat ditangani dengan beberapa langkah diantaranya melalui pengobatan medis, terapi psikologis, tata laksana perilaku, dan pengaturan diet. Pengaturan terapi diet dapat mempermudah pencapaian hasil terapi lainnya. ${ }^{3}$

Diet yang biasa dilakukan untuk penderita autis diantaranya diet Gluten Free Casein Free $(G F C F)$, diet anti yeast/fermentasi dan intoleransi makanan berupa zat pengawet, zat pewarna makanan dan zat penambah rasa makanan. ${ }^{4}$ Perbaikan atau penuruan perilaku autis dapat dilihat dalam waktu 1-3minggu untuk diet Gluten Free Casein Free (GFCF), 1-2 minggu untuk diet anti yeast/fermentasi. ${ }^{5,6}$ Penelitian terkait yang telah dilakukan tahun 2004 di Bogor diperoleh hasil bahwa sebanyak $68,24 \%$ anak autis menunjukkan adanya perbaikan perilaku pada tingkat hiperaktivitas setelah dilakukan terapi diet.

Penelitian lainnya tahun 2012 di Bandung melaporkan bahwa sebanyak $85 \%$ orangtua yang tidak patuh dalam menerapkan diet Gluten Free Casein Free (GFCF) berdampak pada terjadinya gangguan perilaku anak mereka seperti tantrum (mengamuk) dibandingkan pada anak autis yang orangtuanya patuh dalam menjalankan diet. Anak autis yang orangtuanya patuh dalam menjalankan diet membuat perilaku mereka menjadi lebih tenang, emosi lebih stabil dan konsentrasi belajarnya menjadi lebih fokus. Hal ini menunjukkan bahwa frekuensi konsumsi gluten maupun casein memiliki dampak bagi penderita autis $^{4,7}$
Berdasarkan latar belakang tersebut, maka tujuan penelitian ini adalah mengetahui hubungan skor frekuensi diet bebas gluten bebas casein dengan skor perilaku autis.

\section{METODA}

Penelitian ini dilakukan di Pusat Terapi Pendidikan Ananda Bekasi pada bulan AgustusSeptember 2013. Penelitian ini merupakan penelitian cross sectional dalam ruang lingkup gizi masyarakat. Besar sampel yang diperoleh sebanyak 30 anak dan metode pengambilan sampel menggunakan purposive sampling. Sampel yang dipilih merupakan anak autis yang sesuai dengan kriteria inklusi dan eksklusi. Kriteria inklusi meliputi orangtua anak autis yang bersedia mengikuti jalannya penelitian dan menandatangani informed consent, usia anak 3-10 tahun, anak autis yang tidak memiliki gangguan fisik/mental lainnya. Kriteria eksklusinya yaitu mengundurkan diri saat penelitian berlangsung.

Data yang dikumpulkan pada penelitian ini berupa identitas sampel meliputi usia terdiagnosis autis, berat badan lahir, karakteristik orangtua, usia ibu saat hamil subjek, berat badan dan tinggi badan untuk mengukur status gizi yang dianalisis berdasarkan IMT/U menggunakan standar ZScore, kategori obesitas jika > $+2 \mathrm{SD}$, overweight (kelebihan berat badan) jika > +1SD sampai + $2 \mathrm{SD}$, normal jika $\geq-2 \mathrm{SD}$ sampai $\leq+1 \mathrm{SD}$, thiness (kurus) jika $\geq-3 \mathrm{SD}$ sampai $<-2 \mathrm{SD}$, severe thiness (sangat kurus) <-3SD. ${ }^{4}$ Penilaian frekuensi konsumsi diet bebas gluten bebas casein diperoleh melalui FFQ (Food Frequency Questionaire) dengan pola frekuensi tidak pernah dikonsumsi dalam 1-3 minggu terakhir

(skor 0), kurang dari 1 kali per minggu (skor 1), 1-2 kali per minggu (skor 10),

3 kali per minggu (skor 15), 1 kali per hari (skor 25) dan lebih dari 1 kali per hari (skor 50) kemudian dilakukan total skoring, tabel pengamatan perilaku untuk mengukur perubahan perilaku pada anak autis yang diberi nilai skor 020. Penilaian skor dilakukan dengan membandingkan skor 3 bulan yang lalu dan skor sekarang saat pengamatan. Skor dikategorikan menjadi 2 jenis yaitu perilaku autis berkurang jika nilai total skor sekarang (saat pengamatan) lebih kecil dibandingkan dengan total skor 3 bulan yang lalu dan perilaku autis bertambah atau tetap jika total skor sekarang tetap ataupun lebih besar dibandingkan dengan total skor 3 bulan yang lalu.

Pengamatan perilaku tersebut dilakukan dengan menggunakan lembar perilaku ICD-10. 
Perilaku yang diamati yaitu perilaku selama kurang lebih 3 bulan yang lalu berdasarkan buku catatan perkembangan anak dari tempat terapi dan perilaku sekarang saat pengamatan yang dilakukan oleh terapis. $^{9}$

Analisis data untuk mengetahui hubungan skor frekuensi diet bebas gluten bebas casein dengan skor perilaku autis saat ini menggunakan uji korelasi Pearson Product Moment, sebelumnya terlebih dahulu dilakukan uji normalitas menggunakan uji Shapiro Wilk karena data numerik berdistribusi normal.

\section{HASIL \\ Karakteristik subjek penelitian}

Subjek pada penelitian ini berjumlah 30 subjek. Usia subjek berkisar antara 3 sampai 10 tahun. Status gizi subjek diukur berdasarkan indikator IMT/U yang dikonversikan ke nilai ZScore.

Tabel 1. Karakteristik subjek penelitian berdasarkan usia saat penelitian,berat badan,tinggi badan,IMT/U,skor diet BGBC,skor perilaku

\begin{tabular}{lccc}
\hline \multicolumn{1}{c}{ Karakteristik subjek } & Minimum & Maximum & Rerata \pm SD \\
\hline Usia saat penelitian (tahun) & 3 & 10 & $6.67 \pm 2.64$ \\
Berat Badan $(\mathrm{kg})$ & 16 & 67 & $30,95 \pm 13,13$ \\
Tinggi Badan $(\mathrm{cm})$ & 100 & 164 & $130,68 \pm 14,73$ \\
IMT/U (Z-Score) & 1,00 & 5,00 & $2,6 \pm 1,11$ \\
Skor diet BGBC & 51 & 320 & $145,83 \pm 62,63$ \\
Skor perilaku autis & 5 & 20 & $15,17 \pm 3,54$ \\
\hline
\end{tabular}

Hasil penelitian ini menunjukkan bahwa sebagian besar penderita autis adalah laki-laki $(83,3 \%)$. Subjek mulai terdiagnosis autis berkisar antara usia 1-2 tahun (53,3\%).Sebanyak 43,3\% subjek merupakan anak bungsu dalam keluarganya dan sebagian besar subjek memiliki status gizi normal $(46,7 \%)$, meskipun demikian ditemukan pula subjek dengan masalah gizi lebih maupun gizi kurang. Berat badan subjek saat lahir mayoritas antara 2,5-3,0kg $(53,3 \%)$ namun terdapat pula subjek dengan BBLR (berat badan lahir rendah). Karakteristik subjek penelitian selengkapnya dapat dilihat pada tabel 2.

Tabel 2. Karakteristik subjek penelitian berdasarkan jenis kelamin, usia terdiagnosis autis,urutan kelahiran anak,status gizi dan berat badan lahir

\begin{tabular}{lcc}
\hline \multicolumn{1}{c}{ Karakteristik } & Jumlah (n) & Persentase (\%) \\
\hline Jenis Kelamin & 25 & 83,3 \\
Laki-laki & 5 & 16,7 \\
Perempuan & & \\
Usia terdiagnosis autis & 16 & 26,7 \\
$<1$ tahun & 6 & 53,3 \\
$1-2$ tahun & & 20,0 \\
$>2$ tahun & 9 & \\
Urutan kelahiran anak & 2 & 30,0 \\
Sulung & 13 & 6,7 \\
Tengah & 6 & 43,3 \\
Bungsu & & 20,0 \\
Tunggal & 6 & \\
Status Gizi & 6 & 20,0 \\
Obesitas & 14 & 20,0 \\
Overweight & 2 & 46,7 \\
Normal & 2 & 6,7 \\
Kurus & & 6,7 \\
Sangat kurus & 2 & \\
Berat badan lahir & 16 & 6,7 \\
$<2,5 \mathrm{~kg}$ & 12 & 53,3 \\
$2,5-3,0$ kg & & 40,0 \\
$>3,0 \mathrm{~kg}$ & & \\
\hline
\end{tabular}




\section{Karakteristik orangtua subjek}

Pekerjaan orangtua subjek pada penelitian ini sangat bervariasi, sebagian besar ayah subjek bekerja sebagai karyawan swasta $(56,7 \%)$ sisanya ada yang sebagai wiraswasta, PNS serta buruh, sedangkan sebagian besar ibu subjek bekerja sebagai ibu rumah tangga $(70,0 \%)$. Pendidikan terakhir ayah maupun ibu subjek paling banyak adalah perguruan tinggi dengan variasi jenjang pendidikan, Diploma (D1,D2,D3) , sarjana (S1) maupun master (S2). Umumnya jumlah anggota keluarga subjek pada penelitian ini berkisar antara 5-6 orang $(66,7 \%)$. Usia ibu saat hamil subjek bukanlah usia yang muda, hal ini ditandai dengan usia hamil ibu subjek yang sebagian besar > 30 tahun $(63,3 \%)$. Karakteristik orangtua subjek selengkapnya dapat dilihat pada tabel 3 .

Tabel 3. Karakteristik orangtua subjek berdasarkan pendidikan, pekerjaan,jumlah anggota keluarga, dan usia ibu saat hamil subjek

\begin{tabular}{lcc}
\hline \multicolumn{1}{c}{ Karakteristik } & Jumlah (n) & Persentase (\%) \\
\hline Pekerjaan Ayah & 17 & \\
Karyawan swasta & 1 & 56,7 \\
PNS & 12 & 3,3 \\
Wiraswasta & & 40,0 \\
Pendidikan Ayah & 4 & 13,3 \\
SMP & 4 & 13,3 \\
SMA & 22 & 73,3 \\
Perguruan Tinggi & & \\
Pekerjaan Ibu & 21 & 70,0 \\
Ibu rumah tangga & 3 & 10,0 \\
Karyawan swasta & 2 & 6,7 \\
PNS & 4 & 13,3 \\
Wiraswasta & & \\
Pendidikan Ibu & 12 & 40,0 \\
SMA & 18 & 60,0 \\
Perguruan Tinggi & & \\
Jumlah anggota keluarga & 6 & 20,0 \\
3-4 orang & 20 & 66,7 \\
5-6 orang & 4 & 13,3 \\
> orang & & \\
Usia ibu hamil subjek & 2 & 6,7 \\
20-25 tahun & 9 & 30,0 \\
26-30 tahun & 10 & 33,3 \\
31-35 tahun & 9 & 30,0 \\
>35 tahun & &
\end{tabular}

\section{Skor frekuensi diet bebas gluten bebas casein (BGBC)}

Seluruh subjek (100\%) pada penelitian ini masih mengonsumsi makanan yang mengandung gluten maupun casein. Implementasi orangtua subjek saat ini, hanya baru bisa pada tahap mengurangi atau mengatur frekuensi pemberian makanannya saja. Variasi frekuensi konsumsi tersebut, terdapat subjek yang selalu mengonsumsi dalam makanan kesehariannya. Beberapa hal yang melatarbelakangi sulitnya orangtua dalam menjalankan diet diantaranya keterbatasan bahan makanan sebagai alternatif pengganti, makanan yang mengandung gluten dan casein merupakan kesukaan anak, sehingga orangtua merasa tidak tega jika tidak memberikannya.

Tabel 4. Skor frekuensi diet bebas gluten bebas casein (BGBC)

\begin{tabular}{|c|c|c|}
\hline $\begin{array}{c}\text { Skor Frekuensi Diet } \\
\text { BGBC }\end{array}$ & Jumlah (n) & Persentase (\%) \\
\hline $50-100$ & 1 & 3,3 \\
\hline $101-150$ & 6 & 20,0 \\
\hline$>150$ & 23 & 76,7 \\
\hline
\end{tabular}


Berdasarkan tabel 4 nilai skor frekuensi diet bebas gluten casein bebas casein (BGBC) berada pada rentang 50 hingga lebih dari 150 . Subjek yang memiliki skor nilai berkisar antara 50100 mempunyai kebiasaan konsumsi makanan yang mengandung gluten maupun casein tidak lebih dari 1-2kali/ minggu, sedangkan sisanya subjek dengan skor nilai berkisar antara 101-150 dan > 150 mempunyai kebiasaan mengonsumsi makanan yang mengandung gluten maupun casein yang sangat bervariasi. Variasi tersebut bukan hanya berupa kuantitas makanan yang dikonsumsi namun juga dipengaruhi banyaknya jenis makanan yang dikonsumsi. Makanan-makanan yang masih sulit untuk dihindari bagi subjek seperti susu, cokelat, mie instant, serta aneka gorengan yang berbahan dasar terigu.

\section{Skor perilaku autis}

Perilaku autis merupakan gangguan perilaku yang khas pada anak autis. Skor perilaku autis dikategorikan menjadi 2 jenis, yaitu berkurangnya perilaku autis dan tetap atau bertambahnya perilaku autis. Sebagian besar subjek pada penelitian ini masih mengalami gangguan perilaku, hanya $26,7 \%$ saja subjek yang perilaku autisnya berkurang. Berkurangnya perilaku autis tersebut umumnya berupa berkurangnya intensitas hiperaktif pada subjek dan kemampuan subjek dalam melakukan instruksi atau perintah yang diberikan oleh terapis.

Tabel 5. Skor perilaku autis

\begin{tabular}{lcc}
\hline \multicolumn{1}{c}{ Perilaku autis } & Jumlah (n) & Persentase (\%) \\
\hline Berkurangnya perilaku autis & 8 & 26,7 \\
Tetap atau bertambahnya perilaku autis & 22 & 73,3 \\
\hline
\end{tabular}

Tabel 6. Rerata skor perilaku autis

\begin{tabular}{llll}
\hline \multicolumn{1}{c}{ Kategori } & Minimum & $\begin{array}{l}\text { Maximu } \\
\mathrm{m}\end{array}$ & Rerata \pm SD \\
\hline $\begin{array}{l}\text { Skor Perilaku 3bulan yang } \\
\text { lalu }\end{array}$ & 10 & 20 & $16,50 \pm 2,92$ \\
\hline Skor Perilaku sekarang & 5 & 20 & $15,17 \pm 3,54$ \\
\hline
\end{tabular}

Berdasarkan tabel 6 diperoleh hasil bahwa terdapat penurunan rerata skor perilaku autis dari 3 bulan yang lalu dibandingkan dengan skor perilaku yang sekarang.

Hubungan frekuensi diet bebas gluten bebas casein dengan skor perilaku autis
Analisis bivariat menggunakan uji korelasi Pearson Product Moment. Hasil penelitian ini menunjukkan bahwa ada hubungan bermakna antara frekuensi konsumsi diet bebas gluten bebas casein dengan skor perilaku autis. Hal ini dibuktikan secara statistik dengan nilai $\mathrm{p}=0,045$; $\mathrm{r}=0,369$.

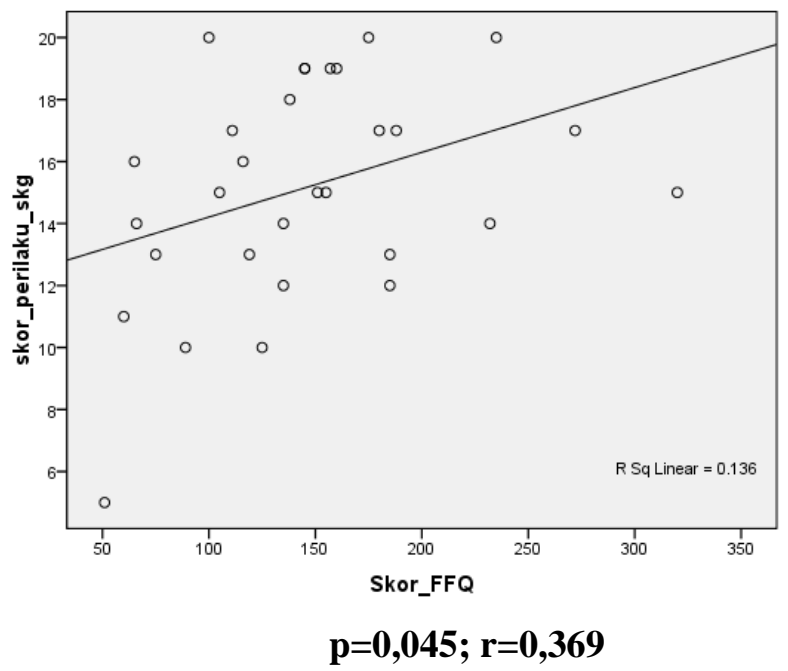

Gambar 1. Hubungan Skor Frekuensi Diet Bebas Gluten Bebas Casein dengan Skor Perilaku Autis. 
Berdasarkan gambar 1 menunjukkan bahwa ada hubungan korelasi positif antara skor frekuensi diet bebas gluten bebas casein dengan skor perilaku autis. Artinya semakin tingginya frekuensi konsumsi makanan yang mengandung gluten maupun casein, maka skor perilaku autis juga akan semakin tinggi.

\section{PEMBAHASAN}

\section{Karakteristik subjek penelitian}

Total subjek dalam penelitian ini sebanyak 30 subjek, terdiri dari 25 laki-laki dan 5 perempuan. Hasil penelitian ini sejalan dengan penelitian-penelitian sebelumnya yang menyatakan bahwa prevalensi penderita autis lebih banyak ditemukan pada laki-laki dibandingkan perempuan $(4: 1)^{3,10}$ Hal ini berkaitan dengan produksi hormon. Laki-laki lebih banyak memproduksi hormon testosteron sedangkan perempuan lebih banyak memproduksi hormon estrogen. Kedua hormon tersebut memiliki efek bertolakbelakang terhadap suatu gen pengatur fungsi otak yang disebut retinoic acid related orphan receptor alpha atau RORA. Hormon testosteron menghambat kerja RORA sedangkan hormon estrogen mampu meningkatkan kinerjanya. Apabila kinerja RORA terhambat maka akan terjadi berbagai masalah koordinasi tubuh, misalnya saja gen tersebut seharusnya melindungi sel saraf dari dampak stress dan inflamasi namun karena kinerjanya terhambat maka sel tersebut tidak mampu bekerja secara baik. $^{11}$

Berat badan lahir subjek sebagian besar berkisar antara 2,5-3,0 $\mathrm{kg}(53,3 \%)$ meskipun demikian ditemukan pula subjek dengan berat badan lahir rendah. Hal ini menunjukkan bahwa risiko autis tidak hanya terjadi pada anak yang lahir dengan berat badan rendah namun juga pada anak yang lahir dengan berat badan normal.Usia subjek terdiagnosis autis pertama kali mayoritas berada direntang usia 1-2 tahun, alasannya karena gangguan perkembangan pada anak sudah bisa diamati sejak anak belum mencapai usia 3 tahun.Salah satu ciri gangguan perkembangan tersebut diantaranya kurangnya responsif kontak mata antara anak dan ibu. ${ }^{12}$

Urutan kelahiran anak berpengaruh terhadap pola asuh pada anak autis, mayoritas subjek pada penelitian ini merupakan anak bungsu dalam keluarganya $(43,3 \%)$. Hal ini tentunya juga berdampak pada status gizinya, sebagian besar subjek memiliki status gizi normal $(46,7 \%)$ namun juga ditemukan pula subjek dengan masalah gizi lebih maupun gizi kurang. Beberapa permasalahan makan pada anak autis diantaranya picky eaters (memilih-milih makanan), kesulitan menerima makanan baru, dan tantrum (mengamuk). ${ }^{23}$

Masalah gizi lebih bisa terjadi pada anak autis dikarenakan orangtua masih beranggapan bahwa diet maupun bentuk pelarangan jenis-jenis makanan tertentu dapat menghambat kebutuhan gizi anak mereka. ${ }^{13,21}$ Penderita autis hanya makan berdasarkan jadwal makan atau makan jika sudah tiba waktu makan, bukan karena lapar. Mereka tidak bisa menakar seberapa banyak makanan yang harus dikonsumsinya, sehingga baru akan berhenti jika makanan tersebut habis atau dihentikan oleh oranglain. ${ }^{14,15}$ Oleh karena itu, dukungan dari orangtua dan anggota keluarga lainnya sangat dibutuhkan untuk kemajuan perkembangan penderita autis.

\section{Karakteristik orangtua subjek}

Pekerjaan orangtua subjek pada penelitian ini sangat bervariasi, namun sebagian besar pekerjaan yang dimiliki oleh ayah subjek adalah karyawan swasta $(56,7 \%)$ dan ibu sebagai ibu rumah tangga $(70 \%)$. Latar belakang pendidikan ayah maupun ibu subjek umumnya lulusan $\mathrm{S} 1$ atau sarjana. Tingginya pendidikan orangtua diharapkan penanganan pada penderita autis juga semakin lebih baik, sebab semakin tinggi tingkat pendidikan seseorang maka semakin tinggi pula kemampuan untuk menyerap informasi, sehingga harapannya penanganannya pun akan semakin lebih baik. ${ }^{9,22}$

Usia ibu saat hamil subjek bukanlah usia yang muda, hal ini ditandai dengan usia hamil ibu subjek yang sebagian besar > 30 tahun $(63,3 \%)$. Hal ini sejalan dengan penelitian di Malang pada tahun 2003 bahwa usia ibu yang hamil > 30 tahun memiliki resiko tinggi terhadap terjadinya gangguan kehamilan maupun persalinan. Semakin tinggi usia ibu saat hamil maka semakin besar pula resiko anak mengalami autis. Beberapa kelainan yang mungkin terjadi adalah pendarahan pada trimester I dan II, berat badan lahir rendah,kasus bayi prematur, maupun komplikasi kehamilan lainnya. ${ }^{16,17}$ Berdasarkan hasil wawancara pada penelitian ini ditemukan bahwa saat hamil subjek beberapa diantaranya pernah mengalami pendarahan, terinfeksi virus tokso, serta adapula yang mengonsumsi obat-obatan terlarang saat hamil.

\section{Skor frekuensi konsumsi diet bebas gluten bebas casein}

Penerapan diet pada penderita autis harus dilakukan secara tetap, teratur dan berkesinambungan untuk melihat manfat dari diet 
tersebut, hal ini tentunya membutuhkan pengawasan yang ketat baik dari orangtua maupun keluarga. ${ }^{18}$ Seluruh $(100 \%)$ subjek pada penelitian ini masih mengonsumsi makanan yang mengandung gluten maupun casein. Berdasarkan wawancara yang dilakukan pada ibu subjek ada beberapa alasan yang melatarbelakangi sulitnya menerapkan diet tersebut diantaranya, faktor psikologis anak, lingkungan keluarga, keterbatasan bahan makanan sebagai alternatif pengganti dan umumnya makanan yang mengandung gluten maupun casein tersebut merupakan makanan kesukaan si anak, sehingga orangtua merasa tidak tega (kasihan) jika tidak memberikannya. Implementasi orangtua dalam menerapkan diet bebas gluten bebas casein, saat ini hanya baru bisa pada tahap mengurangi atau mengatur frekuensi pemberiannya. Pengaturan frekuensi makanan tersebut pun bervariasi disesuaikan dengan kemampuan orangtua dan kondisi anak.

Beberapa contoh bahan makanan yang bisa menjadi alternatif pilihan bagi penderita autis diantaranya tepung beras,tepung beras merah, tepung maizena,tepung kedelai, tepung tapioka, tepung kentang, tepung kanji, tepung singkong,tepung umbi-umbian, bihun, soun, sebagai pengganti terigu (gluten), sedangkan susu kedelai, sari almond, sari kacang hijau sebagai pengganti susu (casein). ${ }^{14}$

Frekuensi konsumsi gluten casein berada pada skor terendah yaitu 51, pengaplikasian dietnya pun berbeda dengan subjek yang memiliki skor tertinggi yaitu 320. Subjek dengan skor konsumsi terendah memiliki kebiasaan mengonsumsi makanan yang mengandung gluten maupun casein yang dibatasi maksimal dalam 1$2 \mathrm{kali} /$ minggu subjek hanya boleh mengonsumsi makanan tersebut,sedangkan subjek dengan skor konsumsi yang tertinggi memiliki kebiasaan mengonsumsi makanan yang mengandung gluten maupun casein hampir setiap hari dalam menu makanannya. Makanan yang menjadi favorit subjek pada penelitian ini antaralain aneka gorengan yang digoreng menggunakan tepung terigu (tahu,tempe, bakwan), mie instant, cokelat dan susu.

Berdasarkan hasil wawancara, umumnya ibu subjek pada penelitian ini sudah mengetahui mengenai diet bebas gluten bebas casein bagi penderita autis. Namun, ada beberapa alasan yang mempengaruhi sulitnya menerapkan diet tersebut diantaranya keterbatasan alternatif bahan makanan pengganti dan anak mudah sakit sehingga apabila makanan tersebut dibatasi maka orangtua khawatir anak tersebut akan kekurangan gizi. Penelitian yang dilakukan di Bandung dan Yogyakarta menyatakan bahwa diet bebas gluten bebas casein selain membuat perilaku autis berkurang juga memiliki manfaat lainnya, penderita autis yang orangtuanya konsisten dalam menjalankan diet tersebut membuat anak mereka menjadi tidak mudah sakit dibandingkan saat belum melakukan diet bebas gluten bebas casein. ${ }^{4,7,24}$

\section{Skor perilaku autis}

Perilaku autis merupakan gangguan perilaku yang khas pada anak autis. Perilaku tersebut meliputi hiperaktivitas anak (gerak gerik yang kurang tertuju), ketidakmampuan anak dalam menatap lawan bicara (eye contact), tidak merespon jika dipanggil, menangis atau tertawa tanpa sebab dan beberapa indikator perilaku khas lainnya. Sebagian besar subjek pada penelitian ini masih mengalami gangguan perilaku, hanya $26,7 \%$ saja subjek yang perilaku autisnya berkurang. Berkurangnya perilaku autis tersebut umumnya berupa berkurangnya intensitas hiperaktif pada subjek dan kemampuan subjek dalam melakukan instruksi atau perintah yang diberikan oleh terapis.

Beberapa faktor yang dapat mempengaruhi perilaku autis diantaranya intensitas terapi, metode terapi, keterlibatan orangtua dan keluarga serta terapi diet. ${ }^{19,20}$ Berdasarkan hasil wawancara pada ibu subjek mayoritas orangtua mengakui bahwa ada pengaruh perilaku autis dengan kebiasaan makan anak. Gangguan perilaku tersebut seperti berkurangnya hiperaktif anak apabila dikuranginya pemberian frekuensi konsumsi susu dan cokelat.

\section{Hubungan frekuensi konsumsi diet bebas gluten bebas casein dengan skor perilaku autis}

Penelitian ini menunjukkan bahwa ada hubungan antara frekuensi konsumsi diet bebas gluten bebas casein dengan perubahan perilaku autis. Tingginya konsumsi bahan makanan yang mengandung gluten dan casein maka akan semakin seringnya terjadi perilaku autis. Hal ini disebabkan oleh tidak sempurnanya proses pemecahan protein yang terkandung dalam gluten dan casein. Gluten dan casein merupakan bagian dari asam amino rantai pendek yang biasa juga disebut peptide. Keadaan normal peptide hanya diabsorbsi sedikit oleh tubuh dan sebagian besar dibuang melalui feses namun tidak demikian pada penderita autis.

Hipermeabilitas pada mukosa usus penderita autis menyebabkan peptide ini meningkat, sebagian peptide diabsorbsi masuk ke sirkulasi aliran darah dan sebagian lagi peptide tersebut menuju otak. Peptide yang menuju ke otak menempel pada reseptor opioid diotak dan berubah 
fungsi seperti morfin. Peptide gluten akan membentuk gluteomorphin atau gliadimorphin dan peptide casein akan membentuk caseomorphin, kedua zat tersebut dapat mempengaruhi sistem saraf pusat sehingga menimbulkan gangguan perilaku. ${ }^{3,15}$ Pernyataan tersebut sesuai dengan observasi yang telah dilakukan pada penelitian ini, bahwa penderita autis yang memiliki kebiasaan frekuensi rendah dalam mengonsumsi makanan gluten maupun casein terjadi perubahan perilaku yang lebih terarah dibandingkan mereka yang memiliki kebiasaan frekuensi yang tinggi dalam konsumsi makanannya. Beberapa perilaku tersebut diantaranya anak menjadi lebih tenang, mudah diberikan instruksi saat terapi, tidak mudah menangis ataupun marah.

\section{SIMPULAN}

Penderita autis lebih banyak ditemukan pada laki-laki dibandingkan perempuan. Kelompok usia terdiagnosis autis paling dominan antara 1-2 tahun dan sebagian besar anak autis merupakan anak bungsu dalam keluarganya. Persentase skor perilaku autis pada penelitian ini hanya $26,7 \%$ saja subjek yang perilaku autisnya berkurang. Status gizi penderita autis berada dalam kategori normal namun ditemukan pula penderita autis dengan status gizi lebih. Seluruh (100\%) subjek pada penelitian ini masih mengonsumsi makanan yang mengandung gluten bebas casein namun penerapannya hanya sebatas mengurangi atau mengatur frekuensi pemberiannya saja. Hasil uji korelasi Pearson menunjukkan bahwa ada hubungan bermakna antara frekuensi konsumsi diet bebas gluten bebas casein dengan skor perilaku autis $(\mathrm{r}=0,369 ; \mathrm{p}=0,045)$

\section{SARAN}

Diet bebas gluten bebas casein pada penderita autis sangat penting untuk mengurangi gangguan perilaku tersebut. Keterbatasan bahan makananan sebagai alternatif pengganti menjadi kendala dalam mengimplementasikannya sehingga diperlukan variasi bahan makanan pengganti yang bebas gluten maupun bebas casein.

\section{DAFTAR PUSTAKA}

1. Mashabi NA,Tajudin NR. Hubungan antara Pengetahuan Gizi Ibu dengan Pola Makan Anak Autis. Makara,Kesehatan Vol 13, 2009 : 84-86

2. Kusumayanti D,Suiraoka, Nursanyoto. Hubungan antara Konsumsi Casein, Gluten dan Pola Aktivitas yang Khas pada Anak Penyandang Autis di Denpasar. Prosiding Temu Ilmiah, Kongres XII Persagi, $2005: 196-202$

3. Nugraheni, SA. Efektivitas Diet Bebas Gluten Bebas Casein terhadap Perubahan Perilaku Anak Autis. Semarang : Pustaka Rizki Putra, 2008

4. Latifah RE. Studi Konsumsi dan Status Gizi pada Anak Penyandang Gangguan Spektrum Autisme di Kota Bogor. Bogor : Fakultas Pertanian,Institut Pertanian Bogor.2004

5. Sutadi R. Autisme. Kongres/Konferensi Nasional Autisme,3-4 Mei,Jakarta.2003

6. Soenardi T.Terapi Makanan Anak dengan Gangguan Autisme.Jakarta : PT.Penerbitan Sarana Bobo. 2009

7. Sofia, AD. Kepatuhan Orang Tua dalam Menerapkan Terapi Diet Gluten Free Casein Free pada Anak Penyandang Autisme di Yayasan Pelita Hafizh dan SLBN Cileunyi Bandung. Bandung : Universitas Padjadjaran, 2012.

8. Rahmawati , Sunartini, Madarina J. Hubungan antara Pola Konsumsi Gluten dan Kasein dengan Skor CARS (Chilhood Autism Rating Scal) pada anak ASD (Autism Spectrum Disorder). Jurnal Gizi Klinik Indonesia $2006: 3: 34-40$

9. Astuti,AT. Hubungan antara Pola Konsumsi Makanan yang Mengandung Gluten dan Kasein dengan Perilaku Anak Autis pada Sekolah Khusus Autis di Yogyakarta. Yogyakarta : Universitas Gajah Mada. 2009

10. Eko,S. Hubungan Karakteristik Ibu dengan Konsumsi Makanan yang mengandung Gluten dan Casein pada Anak Autis. Semarang : Universitas Diponegoro. 2007

11. Alter,Mark D. Autism and Increased Paternal Age Related Changes in Global Levels of Gene Expression Regulation. Public Library of Science ONE Journal. Februari 2013. At http//www.plos.org diakses pada tanggal 30 September 2013

12. Handoyo,Y. Autisma : Petunjuk Praktis dan Pedoman Materi Untuk Mengajar Anak Normal, Autis dan Perilaku Lain. Jakarta : Bhuana Ilmu Populer. 2008

13. Ramadayanti,Sri. Perilaku Pemilihan Makanan dan Kepatuhan Diet Bebas Gluten Bebas Casein pada Anak Autis.Universitas Diponegoro.2012

14. Nugraheni,SA. Penatalaksanaan Diet pada Penyandang Autis. Semarang : Badan Penerbit Universitas Diponegoro.2009

15. Ratnawati,H. Penatalaksanaan Holistik Autisme : Leaky Gut pada Autisme, Pusat Informasi dan Penerbitan Bagian Ilmu Penyakit Dalam Fakultas Kedokteran Universitas Indonesia. Jakarta.2003

16. Muhartomo,Hexanto. Faktor-faktor Resiko yang Berpengaruh terhadap Kejadian Autisme (The Risk Factors of Autism).Tesis.Universitas Diponegoro. 2004

17. Asmika,Andarini Sri dkk. Hubungan Motivasi Orangtua untuk mencapai Kesembuhan Anak 
dengan Tingkat Pengetahuan tentang Penanganan Anak Penyandang Autisme dan Spektrumnya.Universitas Brawijaya.2003

18. Elder,J.H,Shankar,M,Shuster J.The Gluten Free Casein Free Diet in Autism : Results of a preliminary double blind clinical trial.2006. At http//web.ebscohost.com diakses pada tanggal 1 Oktober 2013

19. Firdausia,Fira. Hubungan Perilaku Orangtua Penderita Autisme, Intensitas Terapi dan Usia mulai Terapi dengan Kemajuan Terapi Autisme di Sekolah Luar Biasa (SLB) Autisma Yayasan Pengembangan Potensi Anak (YPAA) Padang. Universitas Andalas. Padang.2008

20. Ningsih, SA. Hubungan Kepatuhan Diet Bebas Gluten Bebas Casein dengan Prestasi Belajar Anak Autis. Semarang : 2010

21. Andica,Febby.Faktor-faktor yang berhubungan dengan Status Gizi pada Anak Autis di Tiga Rumah Autis (Bekasi, Tanjung Priuk, Depok) dan Klinik Tumbuh Kembang Kreibel Depok. Universitas Indonesia. Depok.2012

22. Kurniawati,M.Hubungan antara Pengetahuan dan Sikap Orangtua tentang Autisme dengan Pola Konsumsi dan Status Gizi Anak Autis di Sekolah Luar Biasa Negeri (SLBN) Semarang. Universitas Gadjah Mada.Yogyakarta.2010.

23. Bandini,Linda G. Food Selectivity in Children with Autism Spectrum Disorders and Typically Developing Children.Journal Pediactric on August 2010: 157(2):259-264.

Trisnaningsih,Wulan. Perilaku Makan dan Status Gizi Anak Autis di Yogyakarta. Universitas Gajah Mada.Yogyakarta.2009 